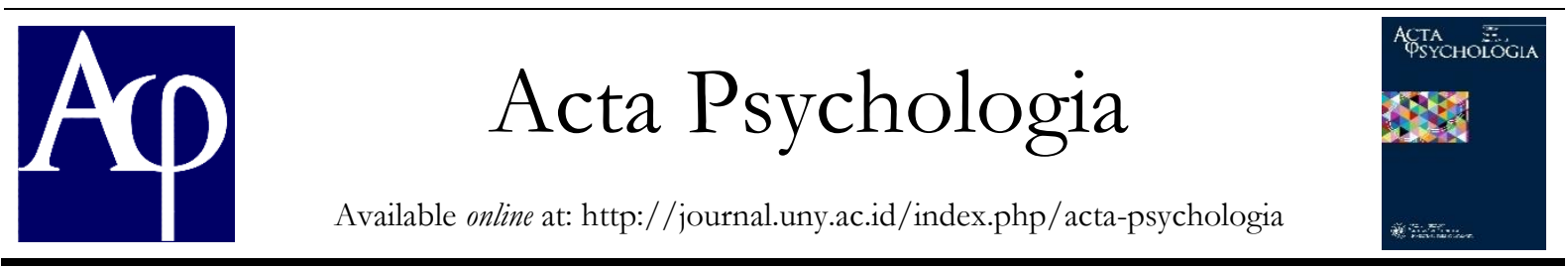

\title{
Pengaruh Kecemasan Komunikasi terhadap Intensitas Penggunaan Media Sosial pada Individu di Usia Emerging Adulthood
}

\author{
Dewinta Galih Wigati, Siti Rohmah Nurbayati \\ Jurusan Psikologi, Fakultas Ilmu Pendidikan, Universitas Negeri Yogyakarta; \\ Jl. Colombo No. 1 Sleman Yogyakarta, 55281 \\ dewintagalih@gmail.com
}

\begin{abstract}
Abstrak
Penelitian ini bertujuan untuk mengetahui pengaruh antara kecemasan komunikasi dengan intensitas penggunaan media sosial pada individu usia emerging adulthood. Penelitian dilakukan di provinsi Daerah Istimewa Yogyakarta dengan menyebarkan kuesioner kepada responden secara online melalui google form. Pengambilan sampel pada penelitian ini menggunakan metode accidental sampling dan mendapatkan 400 responden. Alat pengumpulan data menggunakan skala kecemasan komunikasi dan skala intensitas penggunaan media sosial. Analisis data penelitian ini dilakukan dengan cara uji regresi linier sederhana. Hasil penelitian menunjukkan bahwa kecemasan komunikasi mampu memprediksi intensitas penggunaan media sosial $(F=93,337 ; \alpha=0,000 ; p<0,05)$. Kecemasan komunikasi dapat memprediksi intensitas penggunaan media sosial dengan nilai kontribusi sebesar $19 \%$.
\end{abstract}

Kata Kunci: kecemasan komunikasi, intensitas penggunaan media sosial, emerging adulthood.

\begin{abstract}
This study aims to find out the impact of communication anxiety on the intensity of social media use in individuals at the age of emerging adulthood. The study was conducted in the province of Yogyakarta special region by giving the online questionnaire to the respondents through google form. This research used accidental sampling method and obtained 400 respondents. The data was collected through the scale of communication anxiety and the scale of intensity of social media use. The data analysis technique used the simple linear regression tests. The result of this study showed that communication anxiety was able to predict the intensity of social media use $(\mathrm{F}=93,337 ; \alpha=0,000<0.05)$. Communication anxiety can predict the intensity of social media use with a contribution value of $19 \%$.
\end{abstract}

Keywords: anxiety communication, intensity of social media use, emerging adulthood

\section{Pendahuluan}

Internet merupakan salah satu hasil dari teknologi informasi yang sedang berkembang pada era digital sekarang ini. Internet memberikan kesempatan pada pemakainya di seluruh dunia untuk berkomunikasi. Salah satu situs dalam internet yang menjadi wadah komunikasi adalah Social Networking Sites (SNS) atau biasa dikenal dengan nama media sosial.

Berdasarkan data survey yang dilakukan oleh We Are Social dan
Hootsuite, tercatat bahwa per Januari 2019 sebesar 4.388 miliar orang di seluruh dunia merupakan pengguna internet dan 3.484 miliar orang diantaranya merupakan pengguna aktif media sosial. Di Indonesia sendiri, tercatat bahwa per Januari 2019 sebesar 150 juta orang merupakan pengguna internet dan 150 juta orang tersebut juga merupakan pengguna aktif media sosial. Selain itu, Berdasarkan data yang dikeluarkan oleh Hootsuite We Are Social (2019), pengguna media sosial di Indonesia didominasi oleh masyarakat 
yang berusia di rentang usia 18 hingga 24 sebesar $16,5 \%$ dari total keseluruhan pengguna media sosial. Arnett (2013) mengatakan bahwa di rentang usia tersebut individu berada di masa transisi dari masa remaja ke masa dewasa, atau disebut dengan masa beranjak dewasa (emerging adulthood).

Pada masa emerging adulthood, individu memiliki tugas untuk membentuk relasi yang intim dengan orang lain (Erikson dalam Papalia, 2012). Palupi et al (2016) menyampaikan bahwa komunikasi merupakan salah satu cara yang digunakan oleh individu untuk berinteraksi ke individu lainnya. Komunikasi merupakan hal penting dalam proses interaksi dan sosialisasi, namun secara aktualisasinya masih banyak individu yang merasa cemas ketika ia akan dan atau sedang berkomunikasi.

Pada penelitian yang dilakukan oleh Azka, Firdaus dan Kurniawan (2018) individu di masa emerging adulthood cenderung kurang stabil dalam mengelola hubungan interpersonalnya, sehingga menyebabkan terhambatnya proses interaksi dan komunikasi. Perasaan takut, khawatir, dan cemas akan muncul ketika seseorang mengalami hambatan dalam komunikasi dan interaksi dengan orang lain. Kecemasan tersebut menyebabkan individu mengalami kesulitan dalam menjalin relasi dengan orang lain.

\footnotetext{
Kecemasan menurut Atkinson (1996) merupakan suatu emosi tidak menyenangkan, yang ditandai dengan istilah-istilah seperti 'kekhawatiran', 'keprihatinan', dan 'rasa takut', yang kadang-kadang dialami dalam tingkat yang berbeda-beda. McCroskey

menyampaikan bahwa menurutnya, kecemasan komunikasi, atau yang ia sebut sebagai communication apprehension, adalah suatu rasa takut yang dialami oleh individu yang terkait dengan komunikasi, baik itu secara langsung maupun tidak langsung.
}

Kecemasan komunikasi ini merujuk pada rasa malu, keengganan dalam berkomunikasi, ketakutan berbicara di depan umum, dan sikap pendiam selama interaksi komunikasi (DeVito, 2001). Kecemasan komunikasi merupakan bentuk reaksi negatif dari individu yang dialami ketika berkomunikasi, baik itu komunikasi antar pribadi, komunikasi di depan umum, maupun komunikasi massa (Burgoon \& Ruffner, 1978).

Pada survey pra-penelitian memperlihatkan bahwa sebesar $52,1 \%$ dari total 35 orang individu di masa emerging adulthood di wilayah Yogyakarta mengalami kecemasan komunikasi, yang artinya individu di usia emerging adulthood merasa cemas ketika atau akan terlibat dalam situasi interaksi komunikasi. Seseorang yang mengalami kecemasan komunikasi akan merasa sangat khawatir, gelisah, dan takut ketika ia harus berbicara dengan orang lain, sehingga mereka akan mencari dan bergantung pada media komunikasi yang dapat dilakukan secara non-verbal atau tertulis untuk akses mereka berkomunikasi. Media komunikasi nonverbal ada banyak jenis dan macamnya, namun di era modern dan teknologi seperti sekarang ini, media yang mudah ditemui dan digunakan adalah internet dan media sosial. Media sosial akan dimanfaatkan sebagai satu-satunya media yang efektif bagi seseorang yang memiliki rasa malu, gugup, diam, dan memilih untuk tidak berinteraksi demi menghindari pandangan negatif dari orang lain kepada dirinya (Gecer \& Gumus, 2010).

Sebelumnya telah dijelaskan bahwa individu di usia emerging adulthood ini cenderung kurang stabil dalam mengelola hubungan interpersonal, sehingga ketika individu mengalami kesulitan dalam mengelola hubungan interpersonal maka mereka akan cenderung menggunakan internet dan media sosial, karena kegiatan online dapat memperluas dan memperkuat jaringan dan hubungan sosial mereka 
(Smahel, 2012). Apabila kebutuhan akan komunikasi itu terpenuhi melalui komunikasi di media sosial, mereka yang mengalami kecemasan komunikasi akan lebih memilih untuk berkomunikasi menggunakan media sosial dan cenderung akan menggunakan media sosial lebih intens jika dibandingkan dengan individu yang tidak memiliki kecemasan komunikasi. Hal tersebut dapat menjadi berbahaya ketika media sosial menjadi fokus utama sebagai sarana untuk mendapatkan dukungan sosial dan menjalin hubungan interpersonal mereka, karena hal tersebut dapat mengarah pada perilaku penyalahgunaan internet, yang berupa ketergantungan pada media internet dan media sosial (Soliha, 2015).

Kecenderungan penggunaan media sosial dengan intensitas tinggi terlihat dari hasil survey pra-penelitian yang dilakukan kepada 35 orang individu di masa emerging adulthood di wilayah Yogyakarta. Hasil survey menyatakan bahwa mereka yang menggunakan media sosial, dalam sehari bisa membuka dan mengaksesnya sebanyak lebih dari 4 kali dan waktu penggunaannya selama lebih dari 3 jam per harinya. Penggunaan media sosial tersebut termasuk ke dalam penggunaan media sosial dengan intensitas tinggi.

Berdasarkan uraian di atas maka rumusan masalah penelitian yang diajukan yaitu bagaimanakah pengaruh kecemasan komunikasi terhadap intensitas penggunaan media sosial pada individu di usia emerging adulthood. Tujuan dari penelitian ini adalah untuk meneliti dan mengkaji bagaiaman pengaruh kecemasan komunikasi terhadap intensitas penggunaan media sosial pada individu di usia emerging adulthood. Adapun manfaat dari penelitian ini adalah memperkaya kajian konsep kecemasan komunikasi dan intensitas penggunaan media sosial.

\section{Metode Penelitian}

Jenis Penelitian

Penelitian ini menggunakan pendekatan kuantitatif dengan jenis korelasional.

\section{Waktu dan Tempat Penelitian}

Penelitian ini dilakukan pada bulan Maret-April 2020. Penelitian dilaksanakan di provinsi Daerah Istimewa Yogyakarta.

\section{Populasi dan Sampel Penelitian}

Populasi dalam penelitian ini adalah individu yang berusia 18 hingga 25 tahun di provinsi Daerah Istimewa Yogyakarta. Sampel pada penelitian ini berjumlah 400 orang.

\section{Prosedur Penelitiam}

Penelitian ini terdiri dari beberapa tahap. Tahap pertama adalah penyebaran instrumen (skala kecemasan komunikasi dan skala intensitas penggunaan media sosial) kepada 400 individu di usia emerging adulthood. Tahap selanjutnya adalah seleksi item dan reliabilitas. Seleksi item dilakukan dengan menggunakan bantuan program IBM SPSS for Windows 23. Kriteria pemilihan item berdasarkan korelasi item total menggunakan batasan $\geq 0,30$. Hal tersebut sesuai pendapat Azwar (2015) bahwa batasan minimal koefisien korelasi item-total sebesar 0,30, namun batas tersebut dapat dipertimbangkan untuk diturunkan menjadi 0,20 apabila jumlah butir yang lolos tidak mencukupi jumlah yang diinginkan.

\section{Teknik Analisis Data}

Teknik analisis data yang digunakan dalam penelitian ini adalah analisis deskriptif dan uji hipotesis. Analisis deskriptif meliputi analisis deskriptif subjek dan analisis kategori variabel. Uji hipotesis dilakukan dengan melalui analisis regresi. 


\section{Hasil Penelitian dan Pembahasan}

Berdasarkan hasil analisis karakteristik subjek, ditemukan data sebagai berikut (dapat dilihat pada Tabel 1 dan Tabel 2).Deskripsi Data Statistik Hasil Penelitian Regulasi Emosi

Tabel 1. Data Jenis Kelamin

\begin{tabular}{ccc}
\hline $\begin{array}{c}\text { Jenis } \\
\text { Kelamin }\end{array}$ & Frekuensi & Persentase \\
\hline Perempuan & 267 & $66,75 \%$ \\
Laki-Laki & 133 & $33,25 \%$ \\
Total & 400 & $100 \%$ \\
\hline
\end{tabular}

Tabel 2. Deskripsi Usia Subjek

\begin{tabular}{ccc}
\hline Usia & Frekuensi & Presentase \\
\hline 18 tahun & 32 & $8 \%$ \\
19 tahun & 68 & $17 \%$ \\
20 tahun & 103 & $25,75 \%$ \\
21 tahun & 57 & $14,25 \%$ \\
22 tahun & 74 & $18,50 \%$ \\
23 tahun & 42 & $10,50 \%$ \\
24 tahun & 15 & $3,75 \%$ \\
25 tahun & 9 & $2,25 \%$ \\
Jumlah & 400 & $100 \%$ \\
\hline
\end{tabular}

Berdasarkan hasil deskriptif kategori variabel diperoleh data sebagai berikut (dapat dilihat pada Gambar 1 dan Gambar 2):

1. Kecemasan Komunikasi memiliki rerata 135 dan standar deviasi yang diperoleh adalah 27, sehingga ketegorisasi yang dihasilkan adalah sebagai berikut:

Gambar 1. Hasil Kategorisasi Kecemasan Komunikasi

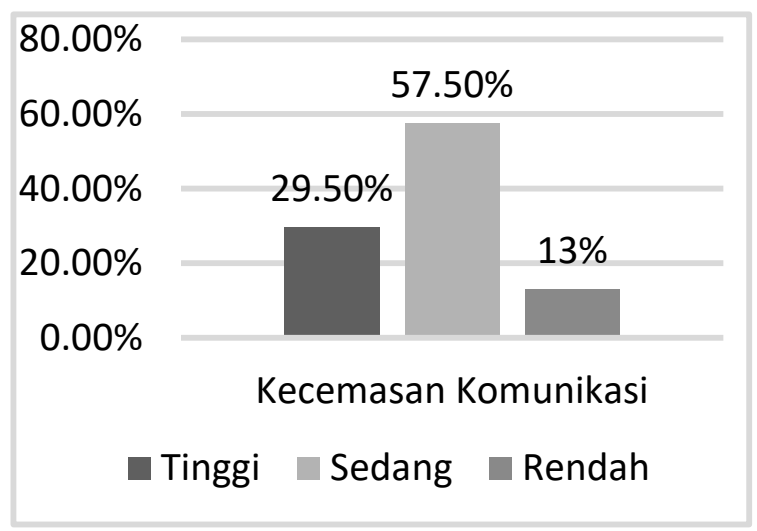

2. Intensitas penggunaan media sosial memiliki nilai rerata 52,5 dan standar deviasi yang diperoleh adalah 10,5, sehingga kategorisasi yang dihasilkan adalah sebagai berikut:

Gambar 2. Hasil Kategorisasi Intensitas Penggunaan Media Sosial

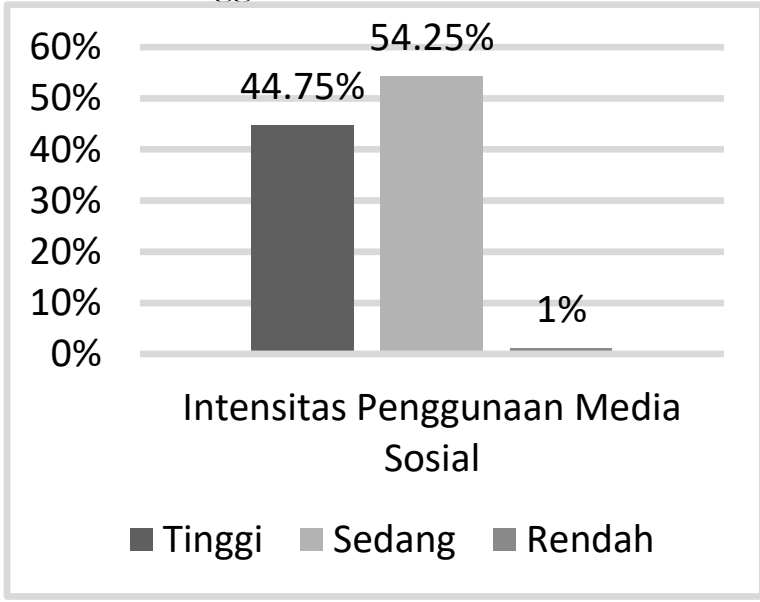

Hasil analisis deskriptif dari kecemasan komunikasi menunjukkan bahwa mayoritas responden merasa bahwa kecemasan komunikasi yang dimilikinya berada pada tingkat sedang dan hanya sedikit responden yang merasa bahwa kecemasan komunikasinya rendah. Hasil analisis deskriptif dari intensitas penggunaan media sosial menunjukkan bahwa mayoritas responden merasa bahwa intensitas penggunaan media sosial yang dimilikinya berada pada tingkat sedang dan hanya sedikit responden yang merasa bahwa intensitas penggunaan media sosialnya rendah.

Uji analisis regresi sederhana dilakukan untuk menguji pengaruh kecemasan komunikasi terhadap intensitas penggunaan media sosial pada individu di usia emerging adulthood. Berdasarkan hasil analisis, ditemukan bahwa variabel kecemasan komunikasi memiliki pengaruh yang bersifat positif terhadap intensitas penggunaan media sosial. Hal tersebut dibuktikan dengan pemerolehan persamaan regresi yaitu $\mathrm{Y}=44,745+$ 
0,154X. Selanjutnya, pada penghitungan koefisien determinan diperoleh hasil nilai $\mathrm{R}$ square sebesar 0,190 yang berarti sebesar $19 \%$ variasi variabel intensitas penggunaan media sosial dapat dijelaskan oleh variasi dari variabel bebas kecemasan komunikasi.

\section{Pada masa emerging adulthood} individu memiliki tugas untuk membentuk relasi yang intim dengan orang lain (Erikson dalam Papalia, 2012). Komunikasi merupakan hal penting dalam proses interaksi dan sosialisasi, namun secara aktualisasinya masih banyak individu yang merasa cemas ketika ia akan dan atau sedang berkomunikasi. Azka, Firdaus, dan Kurniawan (2018) mengatakan bahwa individu di masa emerging adulthood cenderung kurang stabil dalam mengelola hubungan interpersonalnya, sehingga menyebabkan terhambatnya proses interaksi dan komunikasi.

Seseorang yang mengalami kecemasan komunikasi akan merasa sangat khawatir, gelisah, dan takut ketika ia harus berbicara dengan orang lain, sehingga mereka akan mencari dan bergantung pada media komunikasi yang dapat dilakukan secara non-verbal atau tertulis untuk akses mereka berkomunikasi. Mereka akan cenderung menggunakan internet dan media sosial, karena kegiatan online dapat memperluas dan memperkuat jaringan dan hubungan sosial mereka (Smahel, 2012). Apabila kebutuhan akan komunikasi itu terpenuhi melalui komunikasi di media sosial, maka media sosial akan dimanfaatkan sebagai satu-satunya media yang efektif untuk berkomunikasi (Gecer dan Gumus, 2010).

Adanya kecemasan komunikasi pada diri seorang individu akan meningkatkan intensitas penggunaan media sosialnya. Hal tersebut sesuai dengan penelitian Leung (dalam Singgih, 2011), bahwa kecemasan komunikasi, terlepas dari pengertiannya sebagai hambatan dalam berkomunikasi, dapat memicu penggunaan internet dan media sosial dalam berkomunikasi.

Hasil analisis menunjukkan bahwa variabel kecemasan komunikasi memiliki pengaruh terhadap intensitas penggunaan media sosial sebesar 19\%. Hal ini menandakan bahwa kecemasan komunikasi memberikan kontribusi sebesar 19\% terhadap intensitas penggunaan media sosial.

Media sosial pun menjadi sangat dihargai oleh orang-orang yang memiliki kecemasan komunikasi, karena dengan menggunakan media sosial, mereka tidak perlu khawatir akan berkomunikasi dan berinteraksi dengan orang lain, mereka juga tidak perlu khawatir akan adanya kehadiran dan evaluasi dari orang lain Mereka menjadi lebih bebas dan lebih nyaman untuk mengekspresikan diri mereka di media sosial.

\section{Simpulan dan Saran}

\section{Simpulan}

Berdasarkan penelitian yang telah dilakukan, dapat diambil kesimpulan bahwa kecemasan komunikasi dapat memengaruhi intensitas penggunaan media sosial pada individu di usia emerging adulthood. Hal ini berarti bahwa kecemasan komunikasi dalam diri seseorang dapat meningkatkan intensitas penggunaan media sosialnya.

Saran

Kecemasan berkomunikasi menjadi prediktor penggunaan sosial media yang meningkat. Supaya hubungan sosial bisa menjadi lebih dekat, seseorang dapat melanjutkan dengan pertemuan tatap muka untuk mengurangi kecemasan berkomunikasi. 


\section{Daftar Pustaka}

Arnett, J.J. (2013). Adolescence and emerging adulthood fifth edition. Harlow: Pearson Education Inc.

Atkinson, K.C., \& Benn, D.J. (1996). Pengantar psikologi jilid ii edisi XI (Penerjemah: Kusuma W). Jakarta: Erlangga.

Azka, F., Firdaus, D.F., \& Kurniadewi, F. (2018). Kecemasan sosial dan ketergantungan media sosial pada mahasiswa. Psympathic: Jurnal Ilmiah Psikologi, 5(2).

Burgoon, M., \& Ruffner, M. (1978). Human communication. New York: Library of Congress.

DeVito, J.A. (2001). The interpersonal communication book. London: Logman.

Gecer, A.K., \& Gumus, A.E. (2010). Prediction of public and private university students communication apprehension with lecturers. Procedia Social and Behavioral Science, 2, 3008-3014.

McCroskey, J.C. (1982). Communication yearbook 6. United States of America: SAGE Publications, Inc.

Palupi, J., et al. (2016). Keterampilan komunikasi interpersonal mabasiswa tingkat satu. Malang: Universitas Negeri Malang.

Papalia, D.E., Old, S.W., \& Feldman, R.D. (2012). Human development (psikologi perkembangan). Jakarta: Kencana.

Singgih, D. (2011). Penggunaan internet sebagai media komunikasi dalam menciptakan bubungan akrab. Bogor: Institut Pertanian Bogor.

Smahel, D., Brown, B.B., \& Blinka, L. (2012). Associations between online friendship and internet addiction among adolescents and emerging adulthood. Developmental Psychology, 48 (2): 381-288.

Soliha, S.F. (2015). Tingkat ketergantungan pengguna media sosial dan kecemasan sosial. Jurnal Interaksi, 4 (1).

We Are Social, Hootsuite. (2019). Digital 2019: Global internet use accelerates.

Diakses dari http://wearesocial.com/blog/2019 /01/digital-2019-global-internetuse-accelerates 